\title{
Phosphorus in Finnish soils in the 1900s with particular reference to the acid ammonium acetate soil test
}

\author{
Into Saarela \\ MTT Agrifood Research Finland, Environmental Research, FIN-31600 Jokioinen, Finland, \\ e-mail: into.saarela@mtt.fi
}

\begin{abstract}
Comprehensive research into phosphorus (P) in soils and crops began in Finland in the early 1900s. The average amount of total $\mathrm{P}$ in the ploughed topsoil layer of mineral soils was about two tonnes per hectare in the 1930s, before the abundant use of fertilisers. The main chemical fractions of $\mathrm{P}$ in mineral soils were organic matter, primary apatite and secondary complexes of the hydrous oxides of $\mathrm{Al}$ and $\mathrm{Fe}$. Of the smaller amounts of $\mathrm{P}$ in light peat soils, as much as $80 \%$ was present in stable organic compounds. Field experiments showed that the native P reserves of Finnish soils are poorly available to plants, and that $P$ fertilisers are inefficiently utilised because of the strong fixation of applied phosphate in soils. In evaluations before the late 1950s, all simple chemical tests appeared to be rather unreliable indicators of the supply of $\mathrm{P}$ from soils to plants, but later research has shown that the results were impaired by errors implicit in the research materials. Some soil test $\mathrm{P}$ values (STP) obtained from old samples stored for more than ten years evidently were too high, particularly for organic soils, and many of the soils studied were strongly acidic and therefore biologically less fertile than the chemical $\mathrm{P}$ tests indicated. The acid ammonium acetate method ( $\mathrm{pH} 4.65)$ was introduced in the early 1950s and has since been used in routine soil testing in Finland, not only for P but for all macronutrients except $\mathrm{N}$. In later evaluations of different methods used for estimating the requirement of $\mathrm{P}$ fertilisation, the acid ammonium acetate method has proven equal or superior to any other simple chemical method.
\end{abstract}

Key words: acid soils, bioavailability, chemical fractions, old soil samples, total phosphorus

\section{Introduction}

Phosphorus $(\mathrm{P})$ fertilisation has an indispensable role in crop production under the soil and climatic conditions prevailing in Finland, which is recognised as the northernmost agricultural country in the world. Finnish soils are naturally rich in total $\mathrm{P}$, but the reserves occur mostly in relatively insoluble forms, which are poorly available to plants. Generally large but variable yield responses to applied $\mathrm{P}$ were obtained in the 1920s and 1930s in studies in which the requirement for $\mathrm{P}$ fertilisation was assessed by chemi- 
cal soil tests (Tuorila and Teräsvuori 1933, Kaila 1949), and the response curves to increasing rates of $\mathrm{P}$ fertiliser were drawn for several field crops (Tennberg 1950).

Systematic studies on the solubility of $\mathrm{P}$ in fertilisers and soils have been conducted since the beginning of last century (Rindell 1910). Major early topics were the assessment of the total amount and solubility of $\mathrm{P}$ in virgin peats (Kivinen 1933) and mineral soils (Kivinen 1934). Subsequent targets were the chemical fractions of soil $\mathrm{P}$ and the sorption of phosphate in relation to the contents of extractable $\mathrm{Al}$ and $\mathrm{Fe}$ in soils (Salonen 1941) and the amount and characteristics of the organic forms of soil P (Kaila 1948).

The chemical methods proposed for assessing the amount of plant-available $\mathrm{P}$ in soils have been evaluated in several studies (Tuorila and Teräsvuori 1933, Salonen 1939, 1946, Kivinen 1941, Kaila 1949, Teräsvuori 1954, Barkoff 1959, Keränen et al. 1963, Lakanen 1963 and in some later projects). Large-scale testing of soil fertility was initiated early in the 1950s when the acid ammonium acetate extraction method was introduced (Vuorinen 1952, 1953, Vuorinen and Mäkitie 1955). In this method, $25 \mathrm{ml}$ of soil is extracted for one hour with $250 \mathrm{ml}$ of a solution of $0.5 \mathrm{M}$ acetic acid and $0.5 \mathrm{M}$ ammonium acetate ( $\mathrm{pH} 4.65)$.

Research into the amounts, forms and reactions of $\mathrm{P}$ in Finnish soils is discussed in this review paper. Emphasis is on the early studies, which because of their unfamiliar units, such as the soil test $\mathrm{P}$ values presented in $\mathrm{kg} \mathrm{ha}^{-1}$ of superphosphate, are not easily understood by younger researchers. Some old original terms, such as humus soil, used for organic soils with $20-40 \%$ organic matter and now denoted as mould, mull, organic soil or Histosol, are maintained. Many of the old publications are not readily available in libraries but are stored in archives and are not included in databases for electronic search. The early papers nevertheless contain much experimental material still relevant today and suitable for computer modelling. Not least, the original theoretical thinking displayed in the early texts shows us that not all scientific knowl- edge of soils and plant nutrition applied in modern agriculture has been gained during our lifetime.

A particular topic of interest is the development, introduction and later studies on the acid ammonium acetate method, which has been used in routine soil testing in Finland since the 1950s. Some early materials that did not originally support the usefulness of this method in assessing the requirement of $\mathrm{P}$ fertilisation (Kaila 1949, Salonen and Tainio 1957, Barkoff 1959) were restudied in an attempt to understand why it and similar simple tests performed much better in later studies.

\section{Total $\mathrm{P}$ content in soils}

According to Kivinen's summary of 397 samples from soil mapping published in 1934, the average total $P$ concentration of Finnish mineral soils was $830 \mathrm{mg} \mathrm{kg}^{-1}$ (Table 1). As the dry weight of the ploughed topsoil was typically about $2200 \mathrm{t} \mathrm{ha}^{-1}$ (depth $0.2 \mathrm{~m}$, bulk density $1.1 \mathrm{~kg} \mathrm{dm}^{-3}$ ), the mean total $\mathrm{P}$ pool was about $1.8 \mathrm{t} \mathrm{ha}^{-1}$. Because little fertiliser $\mathrm{P}$ had been accumulated prior to this assessment, almost all of the $\mathrm{P}$ pool was natural or had been accumulated from organic fertilisers over a long period of time. Three decades later the total $P$ concentrations in the surface layer of the cultivated mineral soils studied by Kaila (1963b) were almost $30 \%$ higher (Table 1) and their mean value, in now somewhat deepened soils, was equal to $2.5 \mathrm{tha}^{-1}$. While no effect of land use on $\mathrm{P}$ was found in deeper layers, the amounts of total $P$ in the topsoil were about 30 per cent smaller in virgin soils than in cultivated fields. The effect of cultivation, which was also evident in ten pairs of virgin and cultivated mineral soils (Kaila 1963b), implies that several hundred kilogrammes of $P$ per hectare had been accumulated in cultivated fields during the period of traditional organic farming before the 1900s.

According to Salonen (1941), the fusion 
Vol. 11 (2002): 257-271.

Table 1. Total phosphorus and its chemical fractions in cultivated mineral soils according to Kivinen (1934, ref. 1) and Kaila (1963a, 1963b and 1964, ref. 2). P-saturation is the sum of "Al-P" and "Fe-P" divided by the sum of ammonium oxalate soluble $\mathrm{Al}$ and $\mathrm{Fe}$ in moles $\mathrm{kg}^{-1}$.

\begin{tabular}{|c|c|c|c|c|c|c|c|c|c|}
\hline \multirow[t]{2}{*}{ Soil type } & \multirow[t]{2}{*}{ Ref. } & \multirow[t]{2}{*}{$\mathrm{n}$} & \multicolumn{2}{|c|}{ Total $\mathrm{P}, \mathrm{mg} \mathrm{kg}^{-1}$} & \multicolumn{5}{|c|}{ Chemical fractions of soil $\mathrm{P}, \mathrm{mg} \mathrm{kg}^{-1}$ (mean) } \\
\hline & & & Mean & Range & Organic & “Al-P” & "Fe-P" & "Ca-P" & P-satur. \% \\
\hline \multirow[t]{2}{*}{ Sand and fine sand } & 1 & 63 & 670 & & & & & & \\
\hline & 2 & 60 & 860 & $390-1690$ & 260 & 125 & 150 & 145 & 5.4 \\
\hline \multirow[t]{2}{*}{ Silt and loam } & 1 & 101 & 820 & & & & & & \\
\hline & 2 & 69 & 980 & $470-1750$ & 340 & 70 & 150 & 225 & 4.1 \\
\hline \multirow[t]{2}{*}{ Clay } & 1 & 235 & 880 & & & & & & \\
\hline & 2 & 92 & 1170 & $540-1830$ & 390 & 75 & 200 & 210 & 3.7 \\
\hline Humus & 2 & 27 & 1020 & & 490 & & & & \\
\hline
\end{tabular}

method employed by Kaila (1963b) produces more than $10 \%$ higher total $\mathrm{P}$ values than the acid digestion method employed by Kivinen (1934), which does not effectively dissolve silicates. Official fertilisation and crop yield statistics indicate that about $150 \mathrm{~kg} \mathrm{ha}^{-1}$ of $\mathrm{P}$ surplus (input minus output) was accumulated in Finnish farm soils between the early 1930s and early 1960s. Indeed, the values obtained by Kaila (1963b) become compatible with those reported earlier by Kivinen (1934) when the latter are multiplied by 1.15 and the accumulated amount is added. During the 1960s the mean annual P surplus of Finnish cultivated fields was about $15 \mathrm{~kg} \mathrm{ha}^{-1}$, during the $1970 \mathrm{~s}$ and $1980 \mathrm{~s}$ it was $25 \mathrm{~kg} \mathrm{ha}^{-1}$, but in the middle 1990s it dropped sharply to below $10 \mathrm{~kg} \mathrm{ha}^{-1}$. The average total $\mathrm{P}$ accumulation between 1930 and the present has been almost one tonne per hectare.

In addition to the offtake in harvested crops, a significant deduction of applied soil $\mathrm{P}$ from agriculture has occurred through the permanent set-aside of cultivated fields through afforestation, road construction and other land uses. About $10^{5}$ ha of cultivated land was afforested during the 1990s (Tulokas 2001) and, calculating from the average countrywide balance, the total $\mathrm{P}$ enrichment of this land at afforestation was almost $10^{5} \mathrm{t}$. The yearly $\mathrm{P}$ output per hectare of cultivated land in the whole country was nearly $4 \mathrm{~kg}$ and non-negligible in the $\mathrm{P}$ balance. The land removed from cultivation has been partly compensated with newly cleared fields, which contained no accumulated fertiliser $P$. However, the largest part of the P balance surplus of the cultivated soils has evidently been added to the pool of total $\mathrm{P}$ in the ploughed topsoil layer. Calculated according to the $\mathrm{P}$ content determined in the soil 40 years ago and the amounts accumulated subsequently, the present pool of total $\mathrm{P}$ in the plough layer of cultivated mineral soils is approximately $3.0 \mathrm{t} \mathrm{ha}^{-1}$, of which about $30 \%$ has been accumulated during the last seven decades.

In many cultivated fields the topsoil has been diluted with the less fertile subsurface soil through deepened ploughing and transfer of surface soil to the open ditches after subsurface draining. In extreme cases the volume of the fertile topsoil has almost doubled, because ditches and their uncultivated edges may occupy as much as $20 \%$ of the total area and ploughing may have deepened by as much as 1.5 fold $(1.2 \times 1.5=$ $1.8)$. The average increase in the volume of fertile soil per hectare over the last 70 years has probably been at least $15 \%$ (from 2000 to 2300 $\mathrm{m}^{3} \mathrm{ha}^{-1}$ ). The dilution of the topsoil with the less fertile subsurface soil was probably a major reason for the delayed increase in the soil test $\mathrm{P}$ values despite the generally positive $\mathrm{P}$ balances during the 1950s and early 1960s (Kähäri et al. 1987).

The values for mineral and humus soils in Table 1 suggest that the content of total $\mathrm{P}$ does 
Saarela, I. Phosphorus in Finnish soils in the 1900s

Table 2. Total and inorganic phosphorus in virgin peat soils (Kivinen $1933=$ ref 1 , Kaila 1956a and 1956b = ref 2). The amounts of total and inorganic P per hectare denote the means of topsoil layers $0.2 \mathrm{~m}$ deep.

\begin{tabular}{|c|c|c|c|c|c|c|c|}
\hline \multirow[t]{2}{*}{ Peat type } & \multirow[t]{2}{*}{ Ref. } & \multirow[t]{2}{*}{$\mathrm{n}$} & \multicolumn{2}{|c|}{ Total $\mathrm{P}, \mathrm{mg} \mathrm{kg}^{-1}$} & \multirow{2}{*}{$\begin{array}{l}\text { Total P } \\
\mathrm{kg} \mathrm{ha}^{-1}\end{array}$} & \multirow{2}{*}{$\begin{array}{l}\text { Inorganic } \\
\mathrm{mg} \mathrm{kg}^{-1}\end{array}$} & \multirow{2}{*}{$\begin{array}{c}\mathrm{P}(\text { mean }) \\
\mathrm{kg} \mathrm{ha}^{-1}\end{array}$} \\
\hline & & & Mean & Range & & & \\
\hline \multirow{2}{*}{ Sphagnum peat } & 1 & 10 & 370 & $50-720$ & & & \\
\hline & 2 & 32 & 580 & 190-1810 & 260 & 156 & 70 \\
\hline \multirow{2}{*}{ Carex-Sphagnum peat } & 1 & 24 & 580 & $240-960$ & & & \\
\hline & 2 & 34 & 800 & $360-1810$ & 470 & 184 & 108 \\
\hline \multirow[t]{2}{*}{ Sphagnum-Carex peat } & 1 & 24 & 610 & $240-1530$ & & & \\
\hline & 2 & 62 & 800 & $440-1290$ & 490 & 184 & 113 \\
\hline \multirow[t]{2}{*}{ Eutrophic Sph-Carex peat } & 1 & 14 & 580 & $230-830$ & & & \\
\hline & 2 & 12 & 980 & $500-2050$ & 670 & 166 & 114 \\
\hline \multirow[t]{2}{*}{ Carex peat } & 1 & 22 & 690 & $200-1450$ & & & \\
\hline & 2 & 41 & 950 & $450-2350$ & 660 & 180 & 125 \\
\hline \multirow[t]{2}{*}{ Bryales-Carex peat } & 1 & 21 & 710 & $250-1460$ & & & \\
\hline & 2 & 36 & 560 & $260-1190$ & 390 & 120 & 82 \\
\hline
\end{tabular}

not differ with the percentage of organic matter. The virgin peat soils presented in Table 2 also contained almost the same amounts of $\mathrm{P}$ per $\mathrm{kg}$ dry soil, except for some poor Sphagnum peats. However, the variation in $\mathrm{P}$ content is somewhat wider in peats than in mineral soils. With the exception of the Bryales-Carex peat, the older values published by Kivinen (1933) are lower than those reported by Kaila (1956a). Kaila's material included several samples from deeper layers, and total $\mathrm{P}$ often increased with depth (Kaila 1956b); an increase was common in oligotrophic fens and bogs, though the opposite trend was found in some eutrophic peat profiles. The amount and solubility of inorganic $\mathrm{P}$ in peat soils typically decreased with depth. Because of their low bulk densities, virgin peat soils contain much less $\mathrm{P}$ in an equal volume and within the same land area than do mineral soils (Table 2).

\section{Chemical fractions of soil $P$}

In early studies on the solubility of soil $\mathrm{P}, 1 \%$ citric acid was frequently employed as an extracting agent for $\mathrm{P}$ in both peat (Kivinen 1933) and mineral soils (Kivinen 1934). At a soil to solution ratio of $1: 10(\mathrm{w} / \mathrm{v})$, it extracted on average $140 \mathrm{mg} P$ per kg of mineral soil, corresponding to about $20 \%$ of the total pool. In a large number of soil samples, the mean $\mathrm{P}$ concentration obtained by citric acid extraction was 150 $\mathrm{mg} \mathrm{dm}{ }^{-3}$ for coarse mineral soils, $110 \mathrm{mg} \mathrm{dm}^{-3}$ for clay soils and $80 \mathrm{mg} \mathrm{dm}^{-3}$ for organic soils (Vuorinen 1952). Virgin peat soils contained considerably less citric acid soluble $\mathrm{P}$, the mean values for different types of peat ranging from 37 to $78 \mathrm{mg} \mathrm{kg}^{-1}$ (Kivinen 1933). According to Kaila (1948), about one third of the P extracted with citric acid occurs in organic compounds. The mean value of the inorganic part of citric acid extractable $\mathrm{P}, 104 \mathrm{mg} \mathrm{kg}^{-1}$, determined in 150 mineral soils by Kaila (1949) with a modified method, is in good agreement with the values of Kivinen and Vuorinen.

Salonen (1941) compared several methods for determining the total amount and chemical forms of soil $\mathrm{P}$ and quantified the organic and inorganic fractions. He also investigated the sorption of applied $\mathrm{P}$ at different $\mathrm{pHs}$ and found it to correlate with the contents of oxalate extractable $\mathrm{Al}$ and $\mathrm{Fe}$. The $\mathrm{P}$ sorption capacity also depended on these metals in larger collection of mineral soils studied by Kaila (1963c), while soil 
Vol. 11 (2002): 257-271.

$\mathrm{pH}$ and the content of organic matter were of less influence. In peat samples analysed for $\mathrm{Al}$ and Fe with a weaker extractant $(0.1 \mathrm{M} \mathrm{HCl})$ instead of the usual Tamm's oxalate, the most important sorption agent for $\mathrm{P}$ seemed to be Al (Kaila 1959). Some peat samples containing little Al and Fe, mainly unhumified Sphagnum peat, had a very low capacity to sorb P. These kinds of poor peat soils do not retain soluble $P$ from leaching, and the utilisation of applied $\mathrm{P}$ is also accelerated relative to normal Finnish soils.

Kaila further quantified and characterised the organic $(1948,1956 b, 1963 a)$ as well as inorganic (Kaila 1964) fractions of soil P. A summary of her results (Table 1) indicates that about one third of the total $\mathrm{P}$ in mineral soils and a half of that in humus soils was organic. Significant amounts of organic $\mathrm{P}$, on average more than $10 \%$ of the total, were found even in the deeper layers of mineral soils (Kaila 1963a). In the case of Carex and Sphagnum peat, 77-83\% and 73$77 \%$, respectively, of total $\mathrm{P}$ was present in organic compounds (Table 2).

Kaila's studies compiled in Table 1 reveal that the secondary inorganic P fractions, "Al-P" and "Fe-P", together represented a slightly smaller part of soil $\mathrm{P}$ than the organic form. Al-P and $\mathrm{Fe}-\mathrm{P}$ are the fractions sequentially extracted with ammonium fluoride and sodium hydroxide, which have been shown to be selective but not specific extraction agents for the $\mathrm{P}$ forms bound to these metals; they probably extract most of the targeted fractions and some $\mathrm{P}$ from other fractions. The acid extractable fraction "Ca-P", which mainly originates from primary apatite, represented about $20 \%$ of the total P. The surface layer of virgin mineral soils contained much less secondary inorganic $P$ than the cultivated soils, especially the Al-bound form, but organic and Ca-bound $\mathrm{P}$ forms did not differ with land use. The calculated $P$ saturation of oxalate extractable $\mathrm{Al}$ and Fe presented for cultivated surface soils in Table 1 was much lower in virgin surface soils as well as in the deeper layers of all mineral soils. Ca-phosphate was the dominating $\mathrm{P}$ pool in the deeper layers of fine mineral soil, except for the acid sediments of the Lito- rina period, which were rich in $\mathrm{Fe}-\mathrm{P}$ to $0.6 \mathrm{~m}$ depth (Kaila 1963d).

The effects of long-term $P$ fertilisation on the chemical $\mathrm{P}$ fractions in organic soils were assessed by Kaila and Missilä (1956). As with the inorganic fraction, they found substantial changes in the organic fraction in response to fertilisation. Kaila and Ryti (1968) measured the inorganic fractions in Carex peat after 38 years of fertilisation and found the largest changes in the fluoride extractable fraction (Al-P). Barkoff (1959) determined the inorganic $P$ fractions in organic and mineral soils and found changes that were comparable with the calculated P balances. Hartikainen (1989) and Yli-Halla (1989) measured inorganic $\mathrm{P}$ fractions in mineral soils cropped for six to ten years with different rates of $\mathrm{P}$ fertilisation and found significant differences between the treatments. Jaakkola et al. (1997) measured the inorganic and inorganic $\mathrm{P}$ fractions in a heavily limed loam soil after 18 experimental years, but neither the organic nor the acid soluble Ca-bound fraction was affected by P fertilisation. In agreement with the differences between virgin and cultivated soils (Kaila 1964), the largest changes caused by long-term P-fertilisation were found in the fluoride extractable Al-bound fraction, followed by the Fe-bound fraction extracted with $\mathrm{NaOH}$.

The strong sorption of applied $\mathrm{P}$ in Finnish mineral soils, or in other words the rapid transfer of $\mathrm{P}$ from the soluble fertiliser pool to the less available fractions, increases the amount of $P$ fertilisation required for maximum yields. The need for high rates of $\mathrm{P}$ fertiliser application is apparent in a summary of 281 field crop yields with different rates of $\mathrm{P}$ fertilisation in annual experiments conducted in the 1930s and 1940s (Tennberg 1950) and presented in Fig. 1. The essential feature of these results is the linearity of the response curves up to $P$ rates several times the $12 \mathrm{~kg} \mathrm{ha}^{-1}$ that was generally sufficient to replace the $\mathrm{P}$ offtake in harvested crops. This means that large amounts of $\mathrm{P}$ were needed to produce the maximum yields even though the responses were small. There was a more rapid fall in the response per unit $\mathrm{P}$ applied for hay 
Saarela, I. Phosphorus in Finnish soils in the 1900s
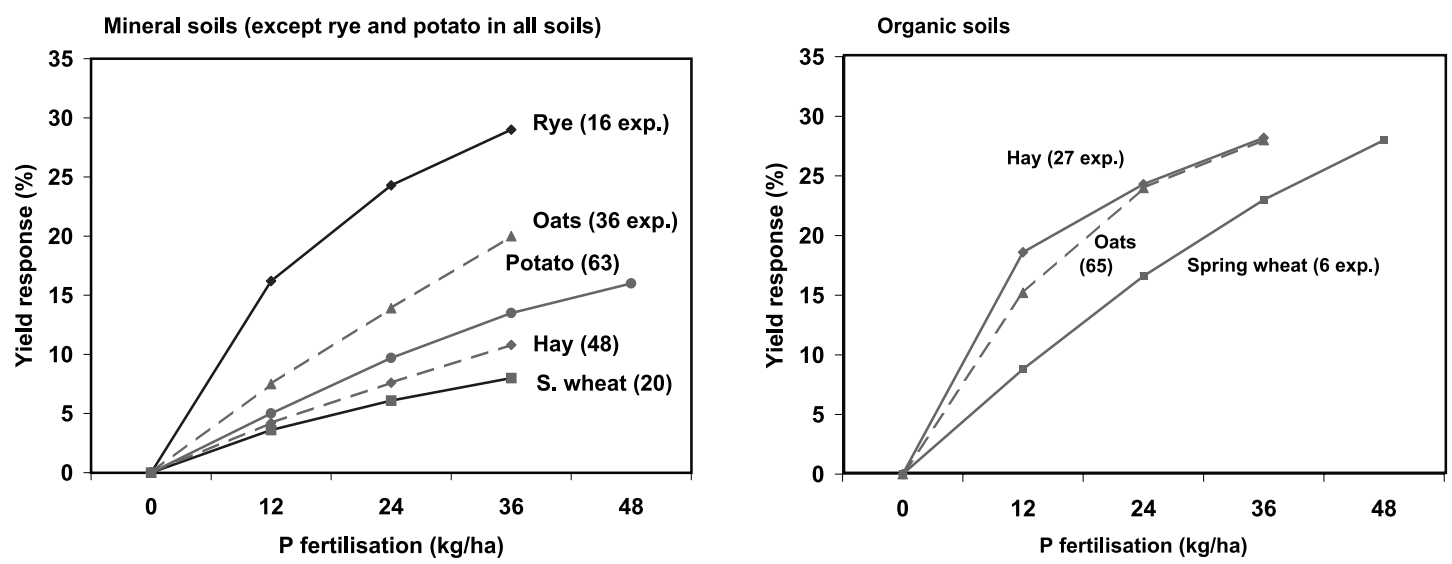

Fig. 1. Effects of short-term phosphorus fertilisation on field crop yields in Finland before the cultivated soils were enriched with long-term application of large amounts of phosphorus (Tennberg 1950). On account of the large number of experiments, the results may be considered highly reliable, even though no statistical tests were made. In the hay grown on organic soils, a minor part of the yield effect of superphosphate used as $\mathrm{P}$ fertiliser is probably attributable to its sulphur.

and oats on organic soils compared to spring wheat, which evidently was mainly grown on soils containing more mineral components capable of sorbing $\mathrm{P}$. The more efficient utilisation of applied $\mathrm{P}$ by crops on peat soils than those on mineral ones was clearly shown in a project involving long-term $\mathrm{P}$ fertilisation experiments (Salonen and Tainio 1957). The better utilisation of applied $\mathrm{P}$ was seen in yield responses, increases in $\mathrm{P}$ uptakes, and also by the quicker changes in soil test $\mathrm{P}$ values (STP).

Unfortunately, many of the old and even recent experiments utilising single superphosphate as the $\mathrm{P}$ source may have been distorted by the calcium $(\mathrm{Ca})$ and sulphur $(\mathrm{S})$ in this fertiliser. Long-term application of $\mathrm{Ca}$ appears to cause minor increases in grass yields on strongly acidic soils. Sulphur has been found deficient in more intensive grass production (Tähtinen 1977), but it was evidently less critical during the extensive cropping before 1950, when the low-grade potassium fertilisers also supplied some S. However, insufficient sulphur has probably retarded plant growth at least in some peat soils in northern Finland. Because even the smallest amounts of superphosphate certainly supplied sufficient $S$, the additional yield increases obtained with short-term application of higher rates of this fertiliser must have been attributable to $P$.

\section{Early studies on plant-available $P$}

As reported by Rindell (1910), the solubility of $\mathrm{P}$ in fertilisers and soils has been investigated since the early 1900 s. Some of the fertiliser analyses presented in that publication were carried out by a young student, L. Kr. Relander, who later became the second president of the Republic of Finland. Rindell's theoretical discussion of the solubility of phosphate was based on physical chemistry and touched upon the difficulty of controlling the hydrogen ion concentration (at that time the concept of $\mathrm{pH}$ was unknown) with the volatile compound carbon dioxide or with strong acids. The possibility of using a mixture of a weak acid and its salt was suggested, and Rindell (1910) actually employed a combination of acetic acid and ammonium acetate. These early considerations and studies were not directly applied in routine soil testing, but they evidently had a delayed influ- 
Vol. 11 (2002): 257-271.

ence on the acid ammonium acetate extraction method, which was later developed in accordance with the suggestions of Pauli Tuorila (Vuorinen 1952, p. 5, 14).

Early research on the plant availability of soil $\mathrm{P}$ was reviewed by Tuorila and Teräsvuori (1933). The purpose of a rapid chemical test for measurement of available soil nutrients was to replace fertilisation experiments and other biological methods, which were too laborious and expensive to determine the highly varying requirements for $\mathrm{P}$ fertilisation of individual fields. Quick colorimetric methods enabled easy determination of low contents of $\mathrm{P}$ in soil extracts, but no reliable methods suitable to dissolve the plant-available fraction of soil $\mathrm{P}$ were known in the 1930s. Although the ability of plants to absorb sufficient $\mathrm{P}$ from dilute soil solutions was already known, it was not understood how the phosphate removed from the soluble pool is replaced from the solid reserves. The acids exuded from plant roots were assumed to play a decisive role in dissolving easily soluble phosphates. This assumed natural process was simulated in the laboratory with weak acids or with diluted solutions of strong acids. An internationally widely used method for measuring plant available $\mathrm{P}$ was the extraction of soils with $1 \%$ solution of citric acid introduced by Dyer (1894). Distilled water had already been tested as the extracting agent, both as pure water and saturated with carbon dioxide, as suggested by Mitscherlich (Rindell 1910).

Water saturated with carbon dioxide (weak acid, $\mathrm{pH}$ 3.8) was evaluated in a preliminary way by Tuorila and Teräsvuori (1933), but later they employed a method based on the P concentrations in a series of dilute nitric acid extracts at $\mathrm{pH} 2-3$. The nitric acid method was developed by Bondorff and Steenberg (1932) and was in use in routine soil testing in Denmark. The results were calibrated with large numbers of fertilisation experiments, but the method was never employed in routine soil testing in Finland. Kivinen (1941) compared this method and the citric acid extraction method with the biological Neubauer test based on $\mathrm{P}$ uptake from soils by rye seedlings and found an effect of $P$ fertilisation on soil $P$ content with all methods.

Salonen evaluated several American rapid tests (1939) and developed some modifications (1946). One of these tests employed acetate buffer $(0.18 \mathrm{M}$ acetic acid, $0.01 \mathrm{M}$ calcium acetate, $\mathrm{pH} 3.7$, extraction ratio $10 \mathrm{ml}$ soil in $100 \mathrm{ml}$ solution, agitation for one hour). Kaila (1949) developed a further version of the acetate test (0.09 $\mathrm{M}$ acetic acid, 0.01 $\mathrm{M}$ sodium acetate, $\mathrm{pH}$ 3.7 , volumetric extraction ratio $1: 5$, extraction time one hour) and evaluated it together with other tests. The acetate tests employed by Salonen (1946) and Kaila (1949) were important steps in the development of the acid ammonium acetate method.

In the Finnish acid ammonium acetate method introduced in the early fifties, (Vuorinen 1952, 1953, Vuorinen and Mäkitie 1955), $25 \mathrm{ml}$ of soil is extracted for one hour with $250 \mathrm{ml}$ of $0.5 \mathrm{M}$ acetic acid and $0.5 \mathrm{M}$ ammonium acetate solution ( $\mathrm{pH} 4.65$ ). The new method was a modification of the Morgan test $(0.54 \mathrm{M}$ acetic acid, $0.70 \mathrm{M}$ sodium acetate, $\mathrm{pH} 4.8$ ) (Morgan 1941), which is in use in the northeastern part of the United States (Jones 1998) and in Ireland (Tunney 1992). In a comparison based on 64 arable Finnish soils, the ammonium acetate method gave about $70 \%$ higher $\mathrm{P}$ values than the Morgan's sodium acetate method (Vuorinen and Mäkitie 1955).

Investigations into the extraction procedure of the acid ammonium acetate method (Mäkitie 1956, 1960) showed the obtained $P$ values to be sensitive to extraction temperature and $\mathrm{pH}$ but less sensitive to extraction time and the amount of soil in a given volume of solution. In repeated extractions with a somewhat lower solution to soil ratio, the maximum $P$ concentrations were not obtained in the first extraction but in the second, third or fourth. The increasing solubility of phosphate was apparently a result of the gradual depletion of cations in the soil, not only $\mathrm{Ca}$ and $\mathrm{Mg}$ but also $\mathrm{Al}$ and $\mathrm{Fe}$. Aluminium and Fe were much more easily extracted with the acid ammonium acetate solution from soils (Mäkitie 


\section{AGRICULTURAL AND FOOD SCIENCE IN FINLAND}

Saarela, I. Phosphorus in Finnish soils in the 1900s

$1960,1968)$ than from their pure phosphate precipitates (Mäkitie 1966).

\section{Why did rapid soil tests initially fail?}

According to tests of 84525 soil samples with the acetate method in the early 1950s and the data computed with IBM punch cards (Janhunen 1961), the soils under rye, oats and hay were almost always infertile (average pH 5.4-5.6, STP 3.3-4.1), and the soils under barley and wheat were not much better (pH 5.7-5.8, STP 4.7-5.7). The low average level and narrow range of the STP values could not allow reliable determination of the differences in the requirement of $\mathrm{P}$ between individual fields. Even during the 1950s, however, the acetate method performed quite well on sugar beet fields (Brummer 1959), most of them being more fertile than the soils under cereals and leys. The apparently improved performances of soil $\mathrm{P}$ tests with their widened ranges were later demonstrated for 30 fertile soils by Aura (1978). In the 15 least fertile soils which contained "little" available P (mean STP $12 \mathrm{mg}$ $\mathrm{dm}^{-3}$ ), the acetate method explained no more than $39.5 \%$ of the variation in the P uptake of potgrown oats, but as much as $76.8 \%$ in the whole collection of 30 soils (mean STP $40 \mathrm{mg} \mathrm{dm}^{-3}$ ).

Some soils studied in long-term field experiments have shown much better P supply to plants than was predicted by the STP values of the surface soil. No yield responses to P fertilisation were apparent during the first eight years on the drained bottom of lake Leistilänjärvi in Nakkila, southwest Finland, where the soil was a weakly acid Gyttja clay that contained 20\% organic matter and had an STP value of only $3.7 \mathrm{mg} \mathrm{dm}^{-3}$ (Salonen and Tainio 1957, exp. 10). It was concluded from the soil testing that the poor yield responses were due to the low content of extractable $\mathrm{Ca}$ in the soil. However, another reason could be that the availability of $\mathrm{P}$ in the subsoil was better than average, which is typical of this kind of young sediment (Kaila 1963d). In later studies, the supply of P to crops seemed to be improved in deep fertile soil profiles on loam soils in Kokemäki close to Nakkila and in Ylistaro (Saarela et al. 1995) as well as on a Gyttja clay soil in Mietoinen (Jaakkola et al. 1977).

Kaila (1949) evaluated and calibrated her own version of the acetate method $(0.09 \mathrm{M}$ acetic acid, 0.01 M sodium acetate, $1 \mathrm{~h}, 1: 5 \mathrm{v} / \mathrm{v}$ ) and four other rapid laboratory tests on the basis of the yield responses of field crops to P fertilisation on mineral soils at 150 sites in Finland. The other methods were the dilute nitric acid extraction at $\mathrm{pH} 2.5,0.5 \mathrm{M}$ acetic acid, $1 \%$ citric acid and acidified calcium lactate. All these methods were found to be more or less unreliable. The research material studied by Kaila (1949) included several strongly acidic and very dense soils. In later studies (Sippola 1980, Saarela and Sippola 1990, Saarela 1992, Saarela et al. $1995)$, the availability of $P$ in such soils was found not to be as good as the chemical soil tests suggested.

According to Sippola's (1980) regression equation based on short-term fertilisation experiments on clay soils at 79 sites, at the lower medium level of STP $\left(6 \mathrm{mg} \mathrm{l}^{-1}\right)$ the increase in grain yield upon application of $40 \mathrm{~kg} \mathrm{P} \mathrm{ha}^{-1}$ was $320 \mathrm{~kg} \mathrm{ha}^{-1}$ when soil $\mathrm{pH}$ was 5.5 and $130 \mathrm{~kg}$ $\mathrm{ha}^{-1}$ at $\mathrm{pH}$ 6.5. The poor availability of $\mathrm{P}$ in relation to STP values in acid soils was even more pronounced in a pot experiment conducted by Saarela (1992). He corrected the STP values for soil acidity by using a simple equation based on $\mathrm{pH}\left(\mathrm{H}_{2} \mathrm{O}\right)$ and the percentage of organic matter $(\mathrm{OM} \%)$, the latter introduced indirectly as coefficients for its four classes. For mineral soils with less than $10 \%$ OM the equation was as follows:

\section{Correction coefficient $=1-0.24 *(7.1-\mathrm{pH})^{2}$}

This equation gives the value of 0.91 at $\mathrm{pH} 6.5$, 0.71 at $\mathrm{pH} 6.0$ and 0.39 at $\mathrm{pH}$ 5.5. In soils with higher percentages of $\mathrm{OM}$, the maximum point of the equation (7.1 at OM\% 0-10) decreased to 
Vol. 11 (2002): 257-271.

6.8 at OM\% 10-20, to 6.6 at OM\% 20-40 and to 6.3 at OM\% 40 or higher. The corrected STP values were obtained from the original $\mathrm{P}$ contents by multiplying them with the correction coefficients. Although this equation was calculated on the basis of just 21 soils, it was successfully applied, in a slightly more sophisticated form, in a larger data set from long-term field experiments (Saarela et al. 1995). With 12 mineral soils in the pot experiment (Saarela 1992), $\mathrm{pH}$ correction was essential to obtain any significant dependencies between the STP values determined by the acetate method and plant parameters. The diffusion test and the water extraction method were not as sensitive as the acetate method to the errors originating from excessive soil acidity. The acid extracting solutions dissolve poorly available $\mathrm{P}$ compounds even from soils that have an unusually high $\mathrm{pH}$, as was shown with a soil collection including heavily limed soils from sugar beet fields (Aura 1978) and with other soils (Jaakkola et al. 1997).

Since soil acidity and physical properties were shown to affect the relationships between the STP values obtained chemically and the real fertility according to plant performance, Kaila's (1949) data, characterised in detail for each of 150 sites, was recalculated by the author. The recalculations, shown in Table 3 , were based on a classification of the experimental sites as infertile soils, more fertile sandy soils and more fertile silt and clay soils. A soil was considered infertile if it had 1) $\mathrm{pH}<4.9$ when a bulk density smaller than 0.9 indicated high content of organic matter, or $\mathrm{pH}<5.2$ in other soils, 2) $\mathrm{pH}>$ 6.2 for sands or 6.5 for silts and clays, 3) bulk density $>1.32 \mathrm{~kg} \mathrm{dm}^{-3}$ or 4) yield $<2400$ feed units $\mathrm{ha}^{-1}$. Altogether 68 soils were classified as infertile and two soils were excluded because of deficient data; that left 80 more fertile soils, 25 of them sands and 55 silts or clays.

As can be seen in Table 3, within the better soils the yields of the control treatment in relation to those obtained with $\mathrm{P}$ fertilisation were significantly correlated with the $\mathrm{P}$ values with all five methods. The dependencies remained rather weak, but as noted by Kaila (1949), an important reason for that is the inability of the yield responses of just one year to indicate the actual $\mathrm{P}$ status of the soil. The decisive superiority of long-term yield responses over one-year results in defining the optimal values of soil STP was shown in a pronounced manner by Munk and Rex (1990). My plotting of the results for Kaila's 80 more fertile soils (results of the plotting not shown) indicated that only negligible yield responses were obtained at the sites with high STP values. However, there were still a number of sites where no response to $P$ fertilisation was obtained in spite of the low STP values.

The soil characteristics used in the classification of Table 3 are available for every field studied by chemical tests and they are even suitable for more sophisticated corrections of STP values (Sippola 1980, Saarela 1992, Saarela et al. 1995). The re-evaluations of the old experimental material suggest that the simple chemical soil tests are more useful than was thought by experienced scientists at mid-century (Mitscherlich 1948). In the nitric acid and citric acid methods the STP values required for sufficient supply of $\mathrm{P}$ from the soil to crops appeared not to depend on soil texture, but the soil $\mathrm{P}$ contents determined by the acetate, acetic acid and lactate methods should be higher in sand soils than was sufficient in silt and clay soils. These relationships between the methods and soil types are in agreement with the original calibrations by Kaila (1949), and also with later studies (Saarela et al. 1995).

Another study in which a rapid soil extraction method was found to fail, in this case the final modification of the acetate method still in use (Vuorinen and Mäkitie 1955), was a series of long-term fertilisation experiments conducted at several sites in Finland (Salonen and Tainio 1957). In addition to the routine extraction tests of this study, soil P reserves were fractionated by ion exchange resins in a system with an automatic recycling of the extracting solution (Barkoff 1959). Anion and cation exchange resins used in combination desorbed rather large amounts of $\mathrm{P}$ even without any chemical addition except water, but 1/15 M KOH was usually 
Saarela, I. Phosphorus in Finnish soils in the 1900s

Table 3. Yields of field crops and soil test $\mathrm{P}$ values obtained by different methods at 148 sites in mineral soils in Finland (Recalculated from Kaila 1949). Soils have been classified according to soil type and the content of P extracted in sodium acetate solution.

\begin{tabular}{|c|c|c|c|c|c|c|c|c|c|}
\hline \multirow{2}{*}{$\begin{array}{l}\text { Acetate P } \\
\text { class } \mathrm{mg} \mathrm{l}^{-1}\end{array}$} & \multicolumn{2}{|c|}{ Soils } & \multicolumn{2}{|c|}{ Yield of no P control } & \multicolumn{5}{|c|}{ Soil test $\mathrm{P}$ values by different methods, $\mathrm{mg} \mathrm{P} \mathrm{kg}^{-1}$ or $\mathrm{l}^{-1}$} \\
\hline & $\mathrm{n}$ & $\mathrm{pH}$ & $\mathrm{FU} \mathrm{ha}^{-1}$ & Relative & Acetate & $\begin{array}{c}\text { Acetic } \\
\text { acid }\end{array}$ & $\begin{array}{c}\text { Citric } \\
\text { acid }\end{array}$ & $\begin{array}{l}\text { Nitric } \\
\text { acid }\end{array}$ & Lactate \\
\hline
\end{tabular}

\begin{tabular}{|c|c|c|c|c|c|c|c|c|c|}
\hline \multirow[b]{2}{*}{$0-1$} & \multicolumn{9}{|c|}{ Infertile soils $\left(\mathrm{pH}<4.9-5.2\right.$ or $>6.2-6.5$ or bulk density $>1.32$ or yield $<2400 \mathrm{FU} \mathrm{ha}^{-1}$ ) } \\
\hline & 31 & 5.3 & 1720 & 76 & 0.6 & 3 & 65 & 0.4 & 8 \\
\hline $1-2$ & 20 & 5.2 & 1890 & 75 & 1.3 & 6 & 90 & 1.2 & 12 \\
\hline $2-4$ & 5 & 5.4 & 1550 & 73 & 3.1 & 13 & 169 & 2.9 & 19 \\
\hline $4-$ & 12 & 6.0 & 2930 & 86 & 13.7 & 38 & 183 & 3.8 & 49 \\
\hline Mean & 68 & 5.4 & 1970 & 77 & 3.2 & 11 & 101 & 1.4 & 17 \\
\hline \multicolumn{5}{|c|}{$\mathrm{R}^{2}$ value (relative yield $\left.=\mathrm{a}+\mathrm{b} * \log \mathrm{P}+\mathrm{c} * \mathrm{pH}\right)$} & $0.06-$ & $0.06-$ & $0.07-$ & $0.02-$ & $0.08-$ \\
\hline \multicolumn{10}{|c|}{ More fertile sandy soils } \\
\hline $0-1$ & 4 & 5.4 & 2860 & 72 & 0.7 & 3 & 41 & 0.2 & 6 \\
\hline $1-2$ & 10 & 5.6 & 3470 & 83 & 1.6 & 6 & 83 & 1.1 & 12 \\
\hline $2-4$ & 4 & 5.7 & 3460 & 98 & 2.8 & 11 & 100 & 1.6 & 19 \\
\hline $4-$ & 7 & 5.7 & 3560 & 99 & 11.8 & 30 & 192 & 3.4 & 46 \\
\hline Mean & 25 & 5.6 & 3400 & 89 & 4.5 & 13 & 110 & 1.7 & 22 \\
\hline \multicolumn{5}{|c|}{$\mathrm{R}^{2}$ value (relative yield $\left.=\mathrm{a}+\mathrm{b} * \log \mathrm{P}+\mathrm{c} * \mathrm{pH}\right)$} & $0.43 * *$ & $0.42 * *$ & $0.37 *$ & $0.43^{* *}$ & $0.32 *$ \\
\hline \multicolumn{10}{|c|}{ More fertile silt and clay soils } \\
\hline $0-1$ & 14 & 5.4 & 2720 & 76 & 0.7 & 3 & 65 & 0.5 & 9 \\
\hline $1-2$ & 21 & 5.6 & 3120 & 92 & 1.3 & 5 & 89 & 1.0 & 10 \\
\hline $2-4$ & 13 & 5.7 & 4400 & 98 & 2.9 & 12 & 130 & 2.1 & 21 \\
\hline $4-$ & 7 & 5.8 & 3490 & 101 & 8.7 & 25 & 191 & 4.0 & 34 \\
\hline Mean & 55 & 5.6 & 3370 & 90 & 2.5 & 9 & 106 & 1.5 & 15 \\
\hline \multicolumn{5}{|c|}{$\mathrm{R}^{2}$ value (relative yield $\left.=\mathrm{a}+\mathrm{b} * \log \mathrm{P}+\mathrm{c} * \mathrm{pH}\right)$} & $0.26 * * *$ & $0.24 * * *$ & $0.26 * * *$ & $0.17 * *$ & $0.25 * * *$ \\
\hline All soils & 148 & 5.5 & 2730 & 83 & 3.2 & 11 & 104 & 1.5 & 17 \\
\hline
\end{tabular}

$\mathrm{FU}=$ feed units. Relative yield of control is in per cent of the yield obtained with $\mathrm{P}$ fertilisation. Asterisks denote the significance $(\mathrm{P})$ of the regression equations: $-=$ not significant, $*=0.05-0.01, * *=0.01-0.001, * * *=0-0.001$.

used as the extraction agent. The yield responses of field crops to long-term $\mathrm{P}$ fertilisation were well predicted with the amounts of $\mathrm{P}$ transferred from soil samples to anion exchange resin in the strongly basic solution. In comparison, the acetate method was found to be much inferior, even rather useless. Salonen and Tainio (1957) had earlier come to the same conclusion with the same research material.

The experimental sites of the studies mentioned above (Salonen and Tainio 1957, Barkoff 1959) included both mineral soils and extremely infertile peat soils. The capacity factor meas- ured by the resin-base extraction of Barkoff (1959) was certainly a much more decisive criterion for $\mathrm{P}$ requirement in such a diverse collection of soils than it would be for normal cultivated Finnish soils. In a recent international comparison of several $P$ tests carried out on Finnish soils (Saarela et al. 1996), the methods that indicated present $\mathrm{P}$ intensity gave less accurate results for the whole diverse collection of organic and mineral soils and more accurate results for the mineral soils alone. Furthermore, the acetate method, being more gentle than the fractionation method, probably gave too high values for 
the old peat samples, which from many sites had been taken more than ten years before analysis.

The increase in the STP values of stored samples was demonstrated recently when the same samples from a series of long-term $\mathrm{P}$ fertilisation experiments (Saarela et al. 1995), first tested in 1977-1981 within one year of sampling, were reanalysed in 1995 (Saarela et al. 1996). The increase in the STP values obtained by the acetate method was on average about $30 \%$ for all surface soils, and still larger for organic soils. The regression equation for the first $\mathrm{P}$ values vs. the later ones was as follows:

$$
\begin{aligned}
\mathrm{STP} 1= & 0.873 * \mathrm{STP} 2-0.00614 * \mathrm{STP} 2 * \mathrm{OM} \% \\
& -0.17\left(\mathrm{R}^{2}=0.967 * * *\right)
\end{aligned}
$$

where STP1 denotes the first determinations, carried out in 1977-1981 within one year of the sampling, and STP2 the later determinations, carried out in 1995. OM\% is the percentage of soil organic matter. For the peat soils not mixed with mineral soil, the equation corrects the later values downwards, sometimes by as much as $70 \%$. I do not know which biological or chemical processes increased the STP values of stored soil samples, but their involvement seemed to be higher in the presence of organic constituents.

Although the correction of the STP values obtained from old soil samples must be considered as rough, it provides a probable explanation as to why a method that appeared to be more or less useless in the early evaluations proved to be more reliable in later studies. The original results of Salonen and Tainio (1957) suggested that large yield increases had been obtained with $P$ fertilisation even in soils with relatively high content of acetate extractable P. However, because of the erroneous STP values caused by too old soil samples, as already suspected by Salonen and Tainio, the actual situation seems to have been not so bad from the viewpoint of chemical soil testing. The large yield responses were evidently obtained at sites which had low STP values at sampling. At least on some peat soils in northern Finland, the yield effects of superphosphate were probably enhanced by its $S$.

\section{Comparison of the acid ammonium acetate method with other $P$ tests}

Keränen et al. (1963) evaluated the Finnish acid ammonium acetate test and three other methods in a study on the P uptake and dry matter yields of pot-grown oats in 14 diverse soils. The other methods were acid ammonium acetate at $\mathrm{pH} 3.75$ (instead of 4.65), acid ammonium lactate (Egner et al. 1960) and $0.01 \mathrm{M} \mathrm{HCl}(1 \mathrm{~g}$ soil per $25 \mathrm{ml})$. The soil test results obtained with all methods correlated quite closely with $\mathrm{P}$ uptake (correlation coefficient $\left.(\mathrm{r})=0.85^{* * *}-0.93 * * *\right)$ as well as with the yields, and no essential differences between the methods were found. Nevertheless, this soil collection, which included three infertile peat samples, evidently favoured the strongest extractants. The correlation coefficients recalculated for the 11 mineral soils, were highest with the two acid ammonium acetate methods (for P uptake $\mathrm{r}=0.93 * * *-0.94 * * *$, for the other two methods $\left.0.83^{* *}-0.86^{* *}\right)$. Even though the number of soils was small, the results suggested that the acid ammonium acetate method is a useful indicator of the availability of soil P to plants.

In several later studies, the acid ammonium acetate method was compared with other chemical P tests developed since the early 1950s. All these studies were based on the actual bioavailability of $\mathrm{P}$ in soils as measured by plant growth, $\mathrm{P}$ uptake or yield responses to $\mathrm{P}$ fertilisation. The tests were evaluated by means of statistical dependencies between the STP values and plant parameters. The explained variations $\left(\mathrm{R}^{2}\right)$ were usually much higher for pot-grown plants than for plants under field conditions. Since the correlation coefficients also increase with widening of the range of STP values without any improvements in the methods (Aura 1978), the absolute values of correlation coefficients are not very informative unless the different methods are compared with use of the same research data.

Methods evaluated with the use of the same soil samples have included different modifications of the ion exchange resin technique and the extraction procedures with water, sodium bicar- 
bonate (Olsen et al. 1954), ammonium lactate and some other solutions (Aura 1978, Sippola and Jansson 1979, Sippola and Jaakkola 1980, Sippola and Saarela 1986, Yli-Halla 1989, 1990, Saarela and Sippola 1990, Saarela et al. 1996). Two additional modifications of the acetate method were studied as well, and even a plant test was evaluated along with the soil tests.

The best accuracy was obtained with the desorption methods by which phosphate ions are chemically collected from soil suspension (Aura 1978, Sippola and Jansson 1979, Sippola and Jaakkola 1980, Sippola and Saarela 1986, YliHalla 1990) or from stationary soil, like plant roots (Saarela 1992, Saarela et al. 1996). The accurate desorption methods are generally considered too laborious for routine soil testing, but a multinutrient ion-exchange resin procedure is employed in routine testing in Brazil (van Raij 1998). In an international comparison of several methods with diverse Finnish soils including also organic soils as the research material, this resin method was the most accurate. A diffusion test was the best in mineral soils (Saarela et al. 1996).

A plant test based on the determination of the inorganic fraction of $\mathrm{P}$ in fresh leaf samples has been shown to be a very sensitive and accurate indicator of P nutrition of plants (Saarela 1990, Saarela and Sippola 1990). With pot-grown plants, the plant test was more accurate than soil tests, but because of the wide variation of the test values with time and other factors, it appeared troublesome to apply in routine testing under Finnish conditions. The water extraction soil test done for $\mathrm{P}$ only has proved as accurate as the acetate test or, particularly in mineral soils, slightly more accurate.

The rather poor performances of the sodium bicarbonate method in Finnish soils (Sippola and Jaakkola 1980, Sippola and Saarela 1986) were contrary to several positive results obtained in other countries (reviewed by Sibbesen 1983). This apparent disrepancy reflects the fundamental differences in the $\mathrm{P}$ sorption mechanisms in acid Finnish soils and neutral and calcareous soils (Teräsvuori 1954). The difference in $\mathrm{pH}$ between the bicarbonate solution and acid soils (2-4 units) is evidently too large to maintain conditions relevant to the rhizosphere soil. In a collection of Finnish mineral soils slightly less acid than average, the bicarbonate method indeed performed equally to the acetate method (Aura 1978).

The acid ammonium acetate solution with a small amount of EDTA added to test for micronutrients (Lakanen and Erviö 1971) was not suitable for testing P (Saarela and Sippola 1990). The addition of $0.003 \mathrm{M}$ ammonium fluoride to the acetate solution (Lakanen 1963) caused a twofold increase in the STP values, with only minor differences in the correlations between the $P$ contents of 220 pairs of hay and soil samples. The most important conclusion to be drawn from the methodological comparisons is that none of the simple chemical soil tests introduced after the Finnish acid ammonium acetate method has been found superior to it for Finnish soils.

Acknowledgements. The author wishes to thank Dr. M. YliHalla for his helpful suggestions, Mrs. Kathleen W. Ahonen for revising the English text and the two anonymous referees for their relevant comments. 
Vol. 11 (2002): 257-271.

\section{References}

Aura, E. 1978. Determination of available soil phosphorus by chemical methods. Journal of the Scientific Agricultural Society of Finland 50: 305-316.

Barkoff, E. 1959. Über die Fraktionierung der Bodenphosphate unter Verwendung eines automatischen Apparates mit lonenaustauscher. Acta Agralia Fennica 94, 12. $36 \mathrm{p}$.

Bondorff, K. A. \& Steenberg, F. 1932. Studier over jordens fosforsyreinhold (Studies on phosphoric acid content of soils). Tidsskrift for Planteav/ 38: 273-308.

Brummer, V. 1959. Lannoituksen vaikutuksesta sokerijuurikkaan satoon. Summary: Effect of fertilization on the yield of sugar beet. Acta Agralia Fennica 94: 201239.

Dyer, B. 1894. On the analytical determination for probably available "mineral" plant food in soils. Journal of Chemical Society, London 65: 115-167. (Ref. Tuorila and Teräsvuori 1933).

Egner, H., Riehm, H. \& Domingo, W. H. 1960. Untersuchungen über die chemische Bodenanalyse als Grundlage für die Beurteilung des Nährstoffzustands der Böden. II. Chemische Extraktionsmethoden zur Phosphor- und Kaliumbestimmung. Kungliga Lantbrukshögskolans Annaler 26: 199-215.

Hartikainen, H. 1989. Effect of cumulative fertilizer dressings on the phosphorus status of mineral soils. Journal of Agricultural Science in Finland 61: 55-66.

Jaakkola, A., Hakkola, H., Köylijärvi, J. \& Simojoki, P. 1977. Effect of liming on phosphorus fertilizer requirement in cereals and ley. Annales Agriculturae Fenniae 16: 207-219.

Jaakkola, A., Hartikainen, H. \& Lemola, R. 1997. Effect of fertilization on soil phosphorus in a long-term field experiment in southern Finland. Agricultural and Food Science in Finland 6: 313-322.

Janhunen, M. 1961. Vilja- ja heinäpeltojen viljavuudesta Suomessa. Summary: Fertility of soils under various crops in Finland. Maatalous ja Koetoiminta 15: 1529.

Jones, J.B., Jr. 1998. Soil test methods: past, present and future use of soil extractants. Communications in Soil Science and Plant Analysis 29: 1543-1552.

Kähäri, J., Mäntylahti, V. \& Rannikko, M. 1987. Suomen peltojen viljavuus 1981-1985. Summary: Soil fertility of Finnish cultivated soils in 1981-1985. Viljavuuspalvelu Oy. $105 \mathrm{p}$.

Kaila, A. 1948. Viljelymaan orgaanisesta fosforista. Summary: On the organic phosphorus in cultivated soils. Valtion maatalouskoetoiminnan julkaisuja 129. 118 p.

Kaila, A. 1949. Maan fosforintarpeen määrittämisestä. Summary: On testing soils for phosphorus deficiency. Reports of State Agricultural Research 220. 26 p.

Kaila, A. 1956a. Phosphorus in virgin peat soils. The Journal of the Scientific Agricultural Society of Finland 28: $142-167$.

Kaila, A. 1956b. Phosphorus in various depths of some virgin peat lands. The Journal of the Scientific Agricultural Society of Finland 28: 90-104.
Kaila, A. 1959. Retention of phosphate by peat samples. The Journal of the Scientific Agricultural Society of Finland 31: 215-224.

Kaila, A. 1963a. Organic phosphorus in Finnish soils. Soil Science 95: 38-44.

Kaila, A. 1963b. Total content of phosphorus in some Finnish soils. The Journal of the Scientific Agricultural Society of Finland 35: 19-26.

Kaila, A. 1963c. Dependence of the phosphate sorption capacity on the aluminium and iron in Finnish soils. The Journal of the Scientific Agricultural Society of Finland 35: 165-177.

Kaila, A. 1963d. Phosphorus conditions at various depths in some mineral soils. The Journal of the Scientific Agricultural Society of Finland 35: 69-79.

Kaila, A. 1964. Fractions of inorganic phosphorus in Finnish mineral soils. The Journal of the Scientific Agricultural Society of Finland 36: 1-13.

Kaila, A. \& Missilä, H. 1956. Accumulation of fertilizer phosphorus in peat soils. The Journal of the Scientific Agricultural Society of Finland 28: 168-178.

Kaila, A. \& Ryti, R. 1968. Effect of application of lime and fertilizers on cultivated peat soil. Journal of the Scientific Agricultural Society of Finland 40: 133-141.

Keränen, T., Barkoff, E. \& Jokinen, R. 1963. Vergleich einiger für die Beurteilung des Nährstoffzustandes der Böden gebräuchlichen chemischen Analysenmethode. Annales Agricuturae Fenniae 2: 19-32.

Kivinen, E. 1933. Suokasvien ja niiden kasvualustan kasvinravintoainesuhteista. Referat: Untersuchungen über dem Gehalt an Pflanzennährstoffen in Moorpflanzen und ihren Standorten. Acta Agralia Fennica 27. $140 \mathrm{p}$.

Kivinen, E. 1934. Über die Pflanzennährstoffverhältnisse der Mineralböden in Finnland. The Journal of the Scientific Agricultural Society of Finland 6: 85-96.

Kivinen, E. 1941. Tutkimuksia maan lannoitustarpeen määräämisestä. Referat: Beiträge zur Bestimmung des Düngungsbedürfnisses des Bodens. Agrogeologisia julkaisuja $52.17 \mathrm{p}$.

Lakanen, E. 1963. Comparison of three extractants used in routine soil analysis. Annales Agriculturae Fenniae 2: 163-168.

Lakanen, E. \& Erviö, R. 1971. A comparison of eight extractants for the determination of plant-available micronutrients in soils. Acta Agralia Fennica 123: 223232.

Mäkitie, O. 1956. Uuttamisesta viljavuustutkimuksessa. Summary: Studies on the acid ammonium acetate extraction method in soil testing. Agrogeologisia julkaisuja $66.25 \mathrm{p}$

Mäkitie, O. 1960. On the extractability of phosphorus by the acid ammonium-acetate soil-testing method. Acta Agriculturae Scandinavica 10: 237-245.

Mäkitie, O. 1966. The solubility of some iron and aluminium phosphates in the acetic acid-ammonium acetate buffer system. Annales Agriculturae Fenniae 5: $6-11$. 
Saarela, I. Phosphorus in Finnish soils in the 1900s

Mäkitie, O. 1968. Aluminium, extractable from soil samples by the acid ammonium acetate soil-testing method. Journal of the Scientific Agricultural Society of Finland 40: 54-59.

Mitsherlich, E.A. 1948. Die "Chemische Bodenanalyse". Zeitschrift für Pflanzenernährung, Düngung, Bodenkunde 42: 97-103.

Morgan, M.F. 1941. Chemical diagnosis by the universal soil testing system. Conneticut Agricultural Experimental Station Bulletin 450: 575-628.

Munk, H. \& Rex, M. 1990. Zur Eichung von Bodenuntersuchungsmethoden auf Phosphat. Summary: Notes on the calibration of phosphate soil testing methods. Agrobiological Research 43: 164-174.

Olsen, S. R, Cole, C. V., Watanabe, F. S. \& Dean, L. A. 1954. Estimation of available phosphorus in soils by extraction with sodium bicarbonate. US Department of Agricuture, Circular 939. 19 p.

Raij, B. van 1998. Bioavailable tests: Alternatives to standard soil extractions. Communications in Soil Science and Plant Analysis 29: 1553-1570.

Rindell, A. 1910. Über Lösligkeitsbestimmungen in der Agriculturchemie. I und II. Akademishe Einladungsschirft. $94 \mathrm{p}$.

Saarela, I. 1990. Inorganic leaf phosphorus as indicator of phosphorus nutrition in cereals. In: Van Beusichem, L.M. (ed.). Plant nutrition - physiology and applications. Developments in Plant and Soil Sciences 41: 779-784.

Saarela, I. 1992. A simple diffusion test for soil phosphorus availability. Plant and Soil 147: 115-126.

Saarela, I., Engblom, S., Kevvai, L., van Raij, B., Sippola, J. \& van der Zee, S. 1996. Present soil testing methods and new nutrient separation techniques as predictors of the responses of field crop yields to phosphorus fertilisation in Finland. Helsinki: Agro-food ry. p. P7. (In Finnish, the original English poster text available at MTT Agrifood Research Finland, Soils and Environment, FIN-31600 Jokioinen, Finland).

Saarela, I., Järvi, A., Hakkola, H. \& Rinne, K. 1995. Fosforilannoituksen porraskokeet 1977-1994. Summary: Phosphorus fertilizer rate trials, 1977-1994. Maatalouden tutkimuskeskus, Tiedote 16/95. 94 p. + 14 app.

Saarela, I. \& Sippola, J. 1990. Inorganic leaf phosphorus and soils tests as indicators of phosphorus nutrition in cereals. Communications in Soil Science and Plant Analysis 21: 1927-1943.

Salonen, M. 1939. Ameriikkalaisten pikamenetelmien käytöstä maan fosfaatti- ja kalilannoitustarpeen määräämiseksi. Summary: The use of American rapid chemical methods in determining the phosphate and potassium fertilizers need of the soils. The Journal of the Scientific Agricultural Society of Finland 11: 271-291.

Salonen, M. 1941. Fosforin esiintymismuodoista Suomen maalajeissa. Zusammenfassung: Über die Formen des Vorkommen von Phosphor in den Bodenarten Finnlands. Acta Agralia Fennica 48. 124 p.

Salonen, M. 1946. Eri uuttomenetelmien vertailua helppoliukoisen fosforihapon esiintymissuhteiden selvittämisessä Etelä-Pohjanmaan kasvinviljelyskoease- man koekentällä. Summary: Comparizon of different extracting methods for determination of easily soluble phosphoric acid on the fields of the agricultural experiment station of Southern East-Bothnia. The Journal of the Scientific Agricultural Society of Finland 18: 80-95.

Salonen, M. \& Tainio, A. 1957. Fosforilannoitusta koskevia tutkimuksia. Summary: Results of field experiments with different amounts of phosphate fertilizers. Publications of the Finnish State Agricultural Research Board 164. 104 p.

Sibbesen, E. 1983. Phosphate soil tests and their suitability to assess the phosphate status of soil. Journal of the Science of Food and Agriculture 34: 13681374.

Sippola, J. 1980. The dependence of yield increases obtained with phosphorus and potassium fertilization on soil test values and soil pH. Annales Agriculturae Fenniae 19: 100-107.

Sippola, J. \& Jaakkola, A. 1980. Maasta eri menetelmillä määritetyt typpi, fosfori ja kalium lannoitustarpeen osoittajina astia- ja kenttäkokeissa (Soil nitrogen, phosphorus and potassium determined by different methods as indicators of fertilisation requirement). Maatalouden tutkimuskeskus, maanviljelyskemian ja -fysiikan laitos, Tiedote 13: 24-40.

Sippola, J. \& Jansson, H. 1979. Soil phosphorus test values obtained by acid ammonium acetate, water and resin extraction as predictors of phosphorus content in timothy (Phleum pratense L.). Annales Agriculturae Fenniae 18: 225-230.

Sippola, J. \& Saarela, I. 1986. Some extraction methods as indicators of need for phosphorus fertilization. Annales Agriculturae Fenniae 25: 265-271.

Tähtinen, H. 1977. The effect of sulphur on the yield and chemical composition of timothy. Annales Agriculturae Fenniae 16: 220-226.

Tennberg, F. 1950. Tuloksia forsfaattilannoitteen nousevien määrien kokeista (Results form experiments with increasing rates of phosphate fertiliser). Maatalous ja koetoiminta 4: 200-210.

Teräsvuori, A. 1954. Über die Anvendung saurer Extraktionslösungen zur Bestimmung des Phosphordüngungsbedarfs des Bodens, nebst theoretischen Erörterungen über den Phosphorzustands des Bodens. Publikationen des Staatlichen Landwirtschaflichen Versuchswesens in Finnland 141. 64 p.

Tulokas, R. 2001. Afforesting of arable land in 1970-1999. In: Environmental Statistics 2001. Statistic Finland. p. 74 .

Tunney, H. 1992. Some environmental implications of phosphorus use in the European Community. In: 4th International Imphos Conference, Ghent, Belgium. p. 347-359.

Tuorila, P. \& Teräsvuori, A. 1933. Untersuchungen über die Anwendbarkeit der bodenanalytischen Methoden zur die Bestimmung des Düngerbedürfnisses. Veröffentlichungen der staatlichen landwirtschaftlichen Versuchstätigkeit 56.48 p.

Vuorinen, J. 1952. Koetilojen peltojen viljavuudesta. Summary: On the fertility of soils on experimental farms in Finland. Agrogeologisia julkaisuja 59. 59 p. + app. 
Vol. 11 (2002): 257-271.

Vuorinen, J. 1953. Koulutilojen peltojen viljavuudesta. Summary: On the fertility of soils on school farms in Finland. Agrogeologisia julkaisuja 60. 44 p. + app.

Vuorinen, J. \& Mäkitie, O. 1955. The method of soil testing in use in Finland. Agrogeological Publications 63. $44 \mathrm{p}$.

Yli-Halla, M. 1989. Effect of different rates of $P$ fertiliza- tion on the yield and $\mathrm{P}$ status in two long-term field experiments. Journal of Agricultural Science in Finland 61: 361-370.

Yli-Halla, M. 1990. Comparison of a bioassay and three chemical methods for determination of plant-available $P$ in cultivated soils in Finland. Journal of Agricultural Science in Finland 62: 213-219.

\title{
SELOSTUS
}

\section{Suomen maaperän fosforin tutkiminen 1900-luvulla ja viljavuustutkimuksen kehittäminen}

\author{
Into Saarela \\ MTT (Maa- ja elintarviketalouden tutkimuskeskus)
}

Maaperän ja lannoitteiden fosforin $(\mathrm{P})$ perusteelliset tutkimukset alkoivat Suomessa 1900-luvun alussa. Fosforin kokonaismäärä oli kivennäismaiden kyntökerroksessa lähes kaksi tonnia hehtaaria kohti jo 1930-luvulla ennen lannoitteiden runsasta käyttöä. Samassa tilavuudessa kevyttä turvetta oli fosforia paljon vähemmän, ja siitä noin neljä viidennestä oli pysyvinä orgaanisina yhdisteinä. Orgaanisen fraktion osuus fosforin kokonäismäärästä oli n. 30 prosenttia myös kivennäismaissa. Epäorgaanisen fosforin pääfraktioita olivat vaikealiukoinen primaarinen apatiitti sekä sekundaariset raudan ja alumiinin oksihydroksidikompleksit, joista jälkimmäiset lisääntyivät fosforilannoituksella eniten.

Lannoituskokeet osoittivat, että maaperämme luontaiset fosforivarat ovat vaikeasti kasvien saatavilla, ja lannoituksen hyväksikäyttö jäi huonoksi maahan lisätyn fosforin lujan pidättymisen takia. Ennen 1950-luvun loppua julkaistuissa tutkimuksissa kaikki yksinkertaiset maan fosforitestit osoittautuivat melko epäluotettaviksi fosforin saannin osoittajiksi, mutta myöhempien tutkimusten valossa tuloksia heikensivät tutkimusaineistoista johtuneet virheet. Maanäytteiden pitkä säilyttäminen ennen analysointia näytti aiheuttaneen liian suuria helppoliukoisen P:n pitoisuuksia erityisesti eloperäisillä mailla. Useat tutkituista pelloista olivat vahvasti happamia ja siksi vähemmän viljavia kuin maan $\mathrm{P}$-analyysi osoitti. Suomalaista hapan ammoniumasetaattimenetelmää, joka kehitettiin 1950-luvun alussa, on sen jälkeen käytetty maassamme ainoana viljavuustutkimuksen rutiinimenetelmänä, ja fosforin lisäksi samasta maauuttesta määritetään muutkin makroravinteet paitsi typpi.

Fosforilannoitustarpeen ennustamiseen käytettyjen menetelmien vertailuissa vain fosforia varten tehtävä vesiuutto ja eräät työläämmät desorptio- ja diffuusiotestit ovat olleet tarkempia, mutta Suomen oloissa asetaattimenetelmä on ollut yhtä hyvä tai parempi kuin mikään muu yksinkertainen kemiallinen menetelmä. 